\title{
GETTING THE MESSAGE ACROSS: EXAMINING MALAYSIA'S COVID-19 PUBLIC SERVICE ANNOUNCEMENT (PSA) INFOGRAPHICS
}

\author{
Collin Jerome* \\ Universiti Malaysia Sarawak \\ Su-Hie Ting \\ Universiti Malaysia Sarawak \\ Yuwana Podin \\ Universiti Malaysia Sarawak
}

\begin{abstract}
The current COVID-19 pandemic has become an unprecedented public health crisis and there is much ongoing research investigating its wide-ranging impacts on all areas of society and people's everyday lives. This article presents preliminary findings of an ongoing study that inquires into Malaysia's COVID-19 public service announcement (PSA) infographics and how they convey much-needed information to the general public during the pandemic period. Drawing upon research on infographics in healthcare and health risk communication, the article examines COVID-19 PSA infographics that have been produced in Malaysia and the ways they achieve what they are designed to do. The findings show that the infographics 1) are numerous and mostly presented in the informational and process-based types, 2) cover various topics related to the information on the novel virus, its risks, and recommended preventive and control measures, 3 ) possess key components of infographic and (4) adopt a three-way process of engaging the target audience. The findings also reveal several key points worth considering in thinking about the infographics, including whether they communicate the right message to the right audience at the right time and whether they are designed according to the principles of message design in health risk communication.
\end{abstract}

Keywords: COVID-19, Public Service Announcement, Infographic, Health Risk Communication, Malaysia.

Received: 25 May 2020

Accepted: 31 December 2020

https://doi.org/10.33736/ijbs.3170.2021

\section{INTRODUCTION}

Public service announcements (henceforth PSAs) are general-interest messages or noncommercial advertisements, which are primarily designed to inform and educate the general public about a particular topic or issue. PSAs take multiple forms and are disseminated to the target audience or specific segments of the population through various mass media channels. Regardless of variety, PSAs perform the same roles, namely to create awareness, affect attitudes,

\footnotetext{
- Corresponding Author: Faculty of Language and Communication, Universiti Malaysia Sarawak, 94300 Kota Samarahan, Sarawak; Tel: +6082-592625; Email: jcollin@unimas.my
} 
and transform actions (Rekhraj, 2015). Such roles are of interest in this study, given that PSAs have the ability to raise awareness and change public opinions on important issues through immediate dissemination of information (Sugget, 2019). PSA infographics, the focus of this study's attention, are a prime example mainly because they present facts or data much more clearly and quickly through "the visualization of information" (Lankow, Ritchie, \& Crooks, 2012). This presentation style affords people the ability to consume and process vast amounts of information quickly and efficiently by harnessing their natural visual power to gain insights and understanding.

PSAs have become even more important today than ever before, especially during the COVID-19 pandemic. Governments the world over, along with non-governmental organizations (NGOs) and community-based organizations (CBOs), have made and continue to make concerted efforts to deal with the pandemic, one of which includes the use of PSA infographics. The World Health Organization (WHO), for instance, has produced many PSA infographics focusing on COVID-19 awareness and prevention measures. These, among others, include COVID-19 Know the Facts, Reduce Your Risk of COVID-19, and A How-To Guide for Physical Distancing, which is made accessible on the WHO official website and social media platforms (WHO, 2020). In a similar vein, Malaysia has taken critical steps towards understanding the new disease and continues to take appropriate control measures in containing the disease and preventing its reemergence and spread. Such steps include the country's own public service announcement campaigns, which are aimed at providing the general public with COVID-19 risk information and prevention messages. We can see this in the PSA infographics produced by the Ministry of Health (henceforth $\mathrm{MOH}$ ), which can be accessed on its official website and social media platforms. Other government agencies, NGOs, and CBOs in Malaysia have undertaken similar efforts to share prevention information via their respective online media platforms.

Although such efforts are not entirely 'novel' given that PSA infographics were used during previous health epidemics or outbreaks, the COVID-19 pandemic has brought a host of new challenges. This is germane in the influx of information on the novel virus due to the increased use of social media and alternate digital media technologies. The spread of 'fake news,' dis/misinformation, propaganda, and social media hoaxes have transformed into an 'information war' (Dzulkifli, 2020; Soo, 2020) that causes fear, panic, confusion, and anger among the public. Two examples are worth mentioning here. The first example is the fake 'Covid-19 Hour' PSA infographic shared on various local social media and mobile platforms (Chan, 2020). The PSA contains, among others, the hashtag \#MalaysiaLockDown and \#SocialDistance, making it "believable" to the untrained or willingly gullible eyes. $\mathrm{MOH}$ was quick to invalidate its authenticity and urged the public to stop it from going viral for safety reasons (Chan, 2020). The second example is the PSA infographic produced by the Women, Family, and Community Development Ministry (WFCDM) as part of its \#wanitacegahcovid19 campaign (Tan, 2020). The PSA was designed to provide 'useful' family tips for housewives and mothers working from home during the Movement Control Order (MCO) period, one of which was to adopt a 'Doraemon-like' tone and giggly manner when dealing with their spouse (Palansamy, 2020). Despite the infographic's 'light-hearted' message, the ministry was lambasted by women groups and netizens for being insensitive, sexist, and misogynistic (Tan, 2020). The ministry was quick to publicly apologize for the oversight and took the infographic down from its Facebook page. 
The above are two of the many examples of PSA infographics produced and shared during the COVID-19 pandemic in Malaysia that may not only have the potential to jeopardize national security and public safety (the first infographic in particular) but also exacerbate ongoing efforts to provide people with much-needed, accurate information in the time of crisis. This is the gap of knowledge that the current study aims to address, considering the efforts taken by the government as well as several NGOs and CBOs to provide accurate, up-to-date information about the pandemic in light of the information overload/information war. Of course, there has already been considerable research into various aspects of PSAs, but the focus has been on nonCOVID-19 related topics such as epilepsy (Martiniuk, Secco, Yake \& Speechley, 2010), prostate cancer (Smith \& Birtwhistle (2012), health and safety campaign (Abd Latiff, Mohd Zulkifli, \& Abd Ghani, 2013; Schroeder, Plapper, Zeng, \& Krile, 2016) as well as local publicity campaign (Chan \& Chang, 2013), to name just a few. This is understandable due to the relative novelty of the disease and the pandemic that people are currently experiencing the world over.

Furthermore, despite the surge of newspaper reports and commentaries on the various aspects of the COVID-19 pandemic in Malaysia, there is little empirical research on the country's COVID19 PSA campaigns. The present study aims to address this gap by examining COVID-19 PSA infographics that have been produced thus far and the ways they achieve what they are designed to do: getting the message across to the target audience. More specifically, the study intends to answer the following research questions: (1) What are the main types of COVID-19 PSA infographics that have been produced so far? (2) What are the main topics covered? (3) What are the key components of these infographics? (4) How do the infographics convey messages about the novel virus to the general public?

\section{LITERATURE REVIEW}

An infographic, as earlier mentioned, (re)presents texts, facts, or data much more clearly through "the visualization of information" (Lankow, Ritchie \& Crooks, 2012). Put simply, an infographic is a (re)presentation of information in a visual or graphic format designed to make data or facts easily understandable at a glance. There is a wide range of infographics based on the information they display and how they display it. These include "isotype arrays," "polar area diagrams," and "charticles" (McCrorie, Donnelly, \& McGlade, 2016), as well as "persuasive infographics," "visual explanations," and "infographic advertisements" (Krum, 2014).

Irrespective of variety and display method, the most common infographic types can be categorised into eight general formats: 1) statistical-based; 2) time-based or chronological; 3) process-based; 4) location-, directional, or geographic-based; 5) information-based; 6) comparison-based; 7) research-based; and 8) demographics (Crane, 2016). These infographics primarily convey large amounts of information vividly, simply, and concisely to the masses for various reasons (e.g., to inform, educate, persuade) and in various contexts or settings (e.g., business, education, technology). Furthermore, infographics generally consist of seven key components -the story, style, simplicity, size, statistics, and/or facts, sources, and shareabilitythat work together to communicate the intended messages.

There are many contexts or settings in which infographics are used, and one of them is healthcare. Studies have shown that infographics play an important role in healthcare, especially healthcare 
communication during the age of digital and social media (McCrorie et al., 2016; Balkac \& Ergun, 2018). In today's digital world where people have become increasingly reliant on (and comfortable with) technology in their daily lives, the healthcare industry is receiving more attention than ever before, thanks to the proliferation of social media and alternate digital media technologies. Recent studies reveal that the relationship between health professionals and the general public is much 'closer' now than before due to several reasons: the increased 1) use of social media by both patients and healthcare providers; 2) likelihood of sharing health information among patients with doctors and hospitals through social media; and 3) consumption of health-related information and discussions of health-related issues among people on social media (Laan, 2013). Such communication and interaction are greatly facilitated by various digital devices, one of which is an infographic.

Healthcare infographics, as Balkac and Ergun (2018) posit, are powerful digital tools that allow people to gain knowledge and information they need to understand particular diseases, specific medical procedures, and trending healthcare topics. These infographics are designed to transform highly complex healthcare information into simple, uncomplicated visual formats that allow a better understanding of the causes, prevention, and treatment of certain diseases (Balkac \& Ergun, 2018). What is more is that infographics have not only enabled health professionals to disseminate healthcare information to patients and the lay public, but also made such information more accessible. This has had an equally profound impact on both healthcare practitioners and patients: healthcare information transmitted via infographics has, on the one hand, enhanced decision-making regarding healthcare among patients while on the other hand, improved practitioner-patient relationships (McCrorie et al., 2016).

An example of this impact can be seen in the 'Start Active, Stay Active' physical activity infographic launched in 2015 by the United Kingdom's chief medical officers (Scott, Fawkner, Oliver, \& Murray, 2016). The infographic, which was distributed to healthcare professionals and the British public via social media, managed to gauge their attention, comprehension, recall, and even adherence through a three-way process: 'raising awareness', 'changing and challenging attitudes' and presenting a 'call to action' to adopt a healthy behavior (Scott et al., 2016). The infographic's 'success' lay in its clear design and easy-to-understand message, with no lengthy explanation by healthcare professionals using complex medical jargon (Scott et al., 2016). Nevertheless, this 'success' should not be taken for granted as studies show that many infographics produced by healthcare professionals and providers did not fully achieve their intended goals.

In a study on infographics created by public health professionals working in Public Health England (PHE) and local authorities, Stones and Gent (2015a) uncovered several key issues affecting the designing and commissioning of the infographics. These issues, among others, include 1) the vast quantities of health data that could not be easily simplified, causing the health professionals to feel overwhelmed by the size of the task; 2) the conflicting design expectations or demands by health professionals and stakeholders (i.e., the former favored a detailed visualization of information, while the latter desired a simplistic style for a non-specialist audience); and 3) the lack of clear guidance in the commissioning of the infographics. Stones and Gent (2015a) concluded that while there was a demand for infographics to be produced and consumed within PHE and their stakeholders, more needs to be done in facilitating their production. This can be achieved through a new set of evidence-based guidelines that Stones and 
Gent have developed to help the production and commissioning of health infographics for use with the general public. These guidelines include seven key principles: 1) get to know your audience; 2) restrict color; 3) align elements, 4) prioritize parts; 5) highlight the heading; 6) invest in imagery (wisely); and 7) choose charts carefully (Stones \& Gent, 2015b).

The designing and commissioning of healthcare infographics can become more complex and demanding in a time of acute public health events such as disease outbreaks or disasters. This is true given that people can be exposed to too much information during such events to the extent that they cannot cope with the information overload (Tran, Valecha, Rad, \& Rao, 2020). In times like these, people expect accurate, trusted information from public health authorities and organizations to assure them that a threat is identified and preventive measures are put in place (Rodriguez \& Kissell, 2013). Quick action must be done (ideally on the same day or within 24 hours) so that people can remain calm and only rely on information from health authorities and organizations, which are widely recognized as credible sources of communication during health emergencies.

Even so, this is not always easy because information tends to change as disease outbreaks evolve (Gamage, Kralovic \& Roselle, 2010). Scholars such as Dur (2014) and Shin (2016) attest that infographics are one of the fastest ways to share vital information during public health emergencies. They maintain that accurate, up-to-date information about a disease outbreak, its risk factors, and the possibilities of prevention can be easily presented to and consumed by the general public and healthcare professionals via infographics (Dur 2014; Shin, 2016). In her study on infographics produced by leading health authorities and organizations during six disease outbreaks, Shin (2016) found that these infographics not only disseminated general information about the disease but also encouraged the public to adopt healthier behavior that could minimize health threats. ${ }^{1}$ While the infographics were found to be useful, Shin discovered that health authorities and organizations took different approaches to present information as evidenced by their use of different graphical elements to suit specific communication goals and organization types. It was also found that the contents of the infographics were largely a reproduction of information materials from the world's leading health organizations (i.e., WHO), resulting in the lack of infographics that catered to people experiencing the disease outbreaks in particular contexts, environments, or regions (Shin, 2016). However, when these infographics did go into production by taking into account the specific conditions of a particular country or region during an epidemic, there were still issues to contend with. In their study on India's Zika virus infographics, Kadri, Rehman, Rehana, and Gergianaki (2016) found that these infographics were mainly written in English because it was (and still is) the official language spoken by the people in the country. This, as Kadri et al., (2016) argued, posed problems for a majority of people who do not speak or understand the language given India's vast and diverse population. There was indeed a necessity for local health authorities to produce Zika virus infographics that were "tailored to the language, readability level and culture of local people" so that the information could be conveyed much more efficiently to the masses (Kadri et al., 2016).

\footnotetext{
${ }^{1}$ The epidemics/outbreaks referred to in Shin's study included Ebola, SARS, MERS, H1N1, Bird Flu, and Zika, while the health authorities and organizations featured comprised the U.S. Centre for Disease Control and Prevention (CDC) and the World Health Organization (WHO), as well as the Ministry of Health and Department of Health in selected regions or countries.
} 
The same can be said of the infographics produced during the COVID-19 pandemic. Although many countries have created their own COVID-19 infographics by reproducing information materials from WHO as 'the global guardian of public health' (Huang, 2020), more needs to be known about these infographics concerning their types, key components, and their particular ways of engaging the target audiences. Besides, more needs to be known about the issues that may arise from the production of these infographics, which are custom-made for the people of a particular country or region. The present study seeks to establish and explore these because of Malaysia's COVID-19 PSA infographics.

\section{METHODOLOGY}

The current study reported is part of a larger research that examines Malaysia's COVID-19 PSA infographics in terms of their production and consumption. The findings presented in the following section are concerned with the production aspect, mainly because it is important at the outset to have some awareness of the types of COVID-19 PSA infographics that have been produced so far, their key components, and the ways they convey messages about the novel disease to the Malaysian public.

To arrive at such an awareness, the present study examined COVID-19 PSA infographics produced by $\mathrm{MOH}$ that is regarded as the country's most credible, reliable, and the authoritative source of information during the pandemic. MOH has so far produced 116 COVID-19 PSA infographics that are made available on its official website and social media platforms such as Facebook and Instagram. ${ }^{2}$ These infographics were downloaded and examined using the following analytical procedures based on previous work in the field (Crane, 2016; Scott et al., 2016; Siricharoen \& Siricharoen, 2015),

1. First, the infographics were read thoroughly to obtain some background information, including the language(s) used, the subject categories, and the topic(s) covered. This information was found in the three important parts of an infographic, namely, the header (e.g., title and brief description), the body (e.g., main text or message), and the footer (e.g., references, copyrights).

2. Next, the infographics were analyzed in terms of their distinct types, namely, the statisticalbased, the time-based, the process-based, the location-based, the information-based, the comparison-based, the research-based, and the demographic-based. The body of each infographic provided the information needed for this procedure.

3. The infographics were then analyzed to determine whether they possessed the key components that make an infographic, which include story, style, simplicity, size, statistics/facts. sources/references and shareability. The three important parts in the infographics were examined for this purpose.

4. Finally, a second thorough reading was conducted to determine how the infographics conveyed the intended messages to the target audience. More specifically, this final procedure

\footnotetext{
2 These infographics were accessed on May 17, 2020, and the numbers and infographics types were updated on daily basis. For more information, see MOH special COVID-19 website at http://covid-19.moh.gov.my/infografik
} 
looked at the three-way process (e.g., raise awareness, change or challenge attitudes, and call to action) that the infographics utilized to engage the target audience.

The results were collated and presented according to the research questions. Issues or problems that may arise from the infographics were also discussed to shed some further light on the importance of effective message design in infographics as an efficient mechanism for disseminating information during public health emergencies.

\section{RESULTS AND DISCUSSION}

The results are presented in three parts: 1) basic information of the infographics; 2) the main types and components of the infographic, and 3) how the infographics convey the intended messages through the three-way process of engaging the target audience.

\subsection{Basic information}

As mentioned earlier, there are 116 infographics produced by $\mathrm{MOH}$ so far during the pandemic period. A total of $97(83.6 \%)$ infographics are written in Malay, followed by $18(15.5 \%)$ in English and one $(0.8 \%)$ in Mandarin. This is understandable, given that Malay is the official national language in Malaysia while English serves as the second most important language after the national language (Omar, 2016). The infographics are further divided by MOH into six groups or subject categories as shown in Table 1.

Table 1: MOH Infographics based on Subject Categories

\begin{tabular}{cc}
\hline \hline Subject Category & $\mathbf{N}(\%)$ \\
\hline Info COVID-19 & $24(20.6 \%)$ \\
Pencegahan & $27(23.2 \%)$ \\
PKP-MCO & $26(22.4 \%)$ \\
Tatacara & $12(10.3 \%)$ \\
Rujukan & $11(9.4 \%)$ \\
Lain-lain & $16(13.7 \%)$ \\
Total & $116(99.6 \%)$ \\
\hline \hline
\end{tabular}

Notes: Info COVID (Information on COVID), Pencegahan (Prevention); PKP-MCO (Perintah Kawalan PergerakanMovement Order Control); Tatacara (Procedures); Rujukan (References); Lain-lain (Others)

The subject categories are further divided into sub-categories based on an analysis of the infographics' topics shown in Table 2.

Table 2: MOH Infographic based on Sub-Categories

\begin{tabular}{cc}
\hline \hline Subject Category & Sub-Categories (i.e., Topic Covered $=\mathbf{N})$ \\
\hline & COVID-19 general info (2) \\
Info COVID-19 & PUI (2) \\
& Protect family members (2) \\
& Break the COVID-19 chain (4) \\
Thank you, Malaysia (1)
\end{tabular}


Advice for those traveling/returning from abroad

Ijtimak Tabligh participants (1)

Face mask (1)

COVID-19 close contact (1)

Don't hide COVID-19 info (1)

Charity (1)

COVID-19 Testing (2)

Protect people at high risk (1)

Use of Neem for COVID-19 (1)

MOH preparedness (1)

Pencegahan

$P K P-M C O$

Tatacara
Minimize the risk of infection (1)

COVID-19 general info (1)

Prevent COVID-19 (e.g., general info, during $\mathrm{MCO}(4)$

Prevent COVID-19 (e.g., program organizers, participant) (2)

Preventive measures (e.g., shopping mall, public transport, workplace, school, front-liners) (6)

Social distancing (e.g., people at risk, 1 meter, workplace, home) (6)

Face mask (3)

Hand washing (1)

Break the COVID-19 chain (1)

Protect family, community, and environment (2)

Staying healthy at home (11)

Why stay at home (3)

What can one do at home (1)

MCO general info (2)

MCO (e.g., medical appointments, visitors, health department) (3)

Family/Spousal relation (2)

Prevent dengue during MCO (1)

At old folk's home (1)

Advice for civil servants (1)

Working from home/at the workplace (1)

Screening for travelers and crews from China (1)

COVID-19 prevention (1)

Cleaning and disinfecting (2)

Advice for employers (1)

Positive COVID-19 cases (1)

Contact screening (2)

Guidelines for healthcare workers (2)

Dispose of face mask (1)

Screening for healthcare workers (1) 


\begin{tabular}{cc}
\hline \hline Subject Category & Sub-Categories (i.e., Topic Covered = N) \\
\hline List of hospitals for screening (1) \\
CPRC hotline/contact number (2)* \\
List of hospitals and public medical labs for \\
detection (1) \\
MHPSS (1)* \\
Reservation of medical appointments (1) \\
Important COVID-19 information (2) \\
JKN contact number (1)* \\
Psycho-social support contact number (1) \\
\\
Advice for taxi/e-hailing drivers (2) \\
Advice for taxi/e-hailing passengers (2) \\
Managing stigma (2) \\
Managing emotions for medical front-liners (1) \\
Emotional and Psychological change (1) \\
Mindset shift (2) \\
Managing burnout (1) \\
Managing stress due to MCO (1) \\
Home surveillance steps (3) \\
Home surveillance criteria (1)
\end{tabular}

Notes: *PUI - Person Under Investigation; CPRC - Crisis Preparedness and Response Centre; MPHSS -Mental Health and Psychological Support; JKN - Jabatan Kesihatan Negeri (State Health Department)

The first two groups of infographics, namely, Info COVID-19 (information about COVID-19) and Pencegahan (Prevention) come as no surprise simply because information about a disease outbreak (in this case, COVID-19 pandemic), its risk factors, and the possibilities of prevention must be presented and consumed by the general public in times of acute health conditions (Dur 2014; Shin, 2016). The remaining groups such as Tatacara (Procedures) and Lain-lain (Others) are equally important as they provide further information that can be used by the laypeople to minimize the impact of COVID-19 by complying with preventive and treatments measures, as well as seeking medical help and support.

The infographics under the PKP-MCO group are expected to provide essential information on priority actions to be taken either by healthcare professionals or by the general public during the Movement Control Order implemented by the Malaysian government as a preventive measure in response to the COVID-19 pandemic. Topics covered by the PKP-MCO infographics are mainly designed to raise awareness about this response measure, particularly on what and why certain things need to be done (e.g., staying at home) during the movement control order period to combat the spread of the disease.

\subsection{Types and Components of Infographic}

In terms of the infographic type shown in Table $3, \mathrm{MOH}$ has produced a more process-based type (56 or $48.2 \%$ ), followed by the information-based type (55 or $47.4 \%$ ). Only four $(3.4 \%)$ infographics are of the location-based type and one ( $0.8 \%)$ comparison-based type. 
Announcement (PSA) Infographics

Table 3: MOH Infographics according to Main Types

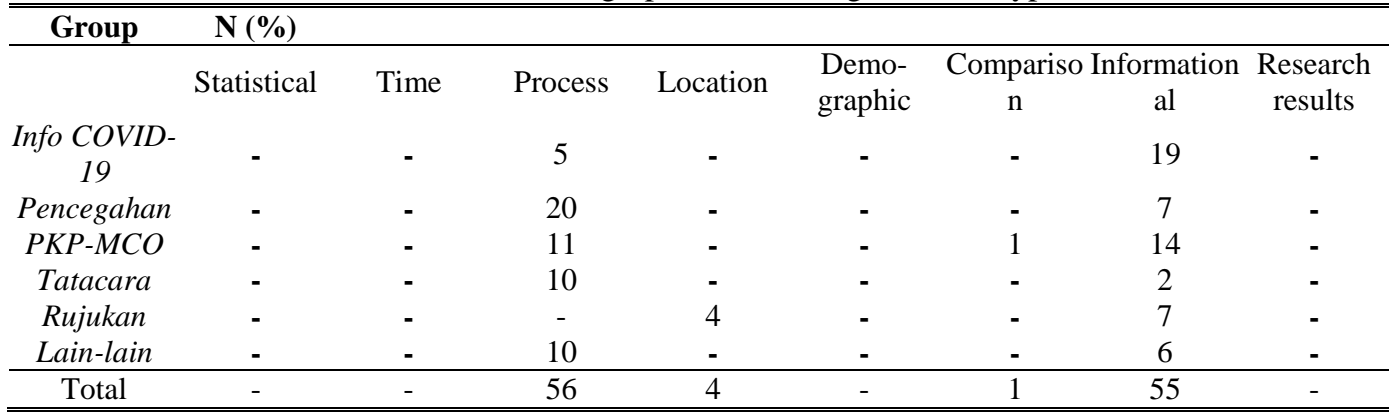

This comes as no surprise because information about COVID-19 can 'best' be presented via the informational type to make it easily and clearly understood. Informational infographics, as Knorr (2019), "tell a story using formatted icons, bullet points, and sections that divide the content up into logical categories" (p. 103). This can be observed in, for example, the Pengunaan daun semabu (neem) bagi wabak COVID-19 (The use of neem for COVID-19 epidemic) infographic under the Info COVID-19 infographic group (Figure 2). The infographic uses formatted icons (e.g., medical mortar and pestle, virus, patient, and death skull) and sections (e.g., Mitos/Myths and Fakta/Facts) to separate the main message into coherent categories.

Figure 2: Pengunaan daun semabu (neem) bagi wabak COVID-19

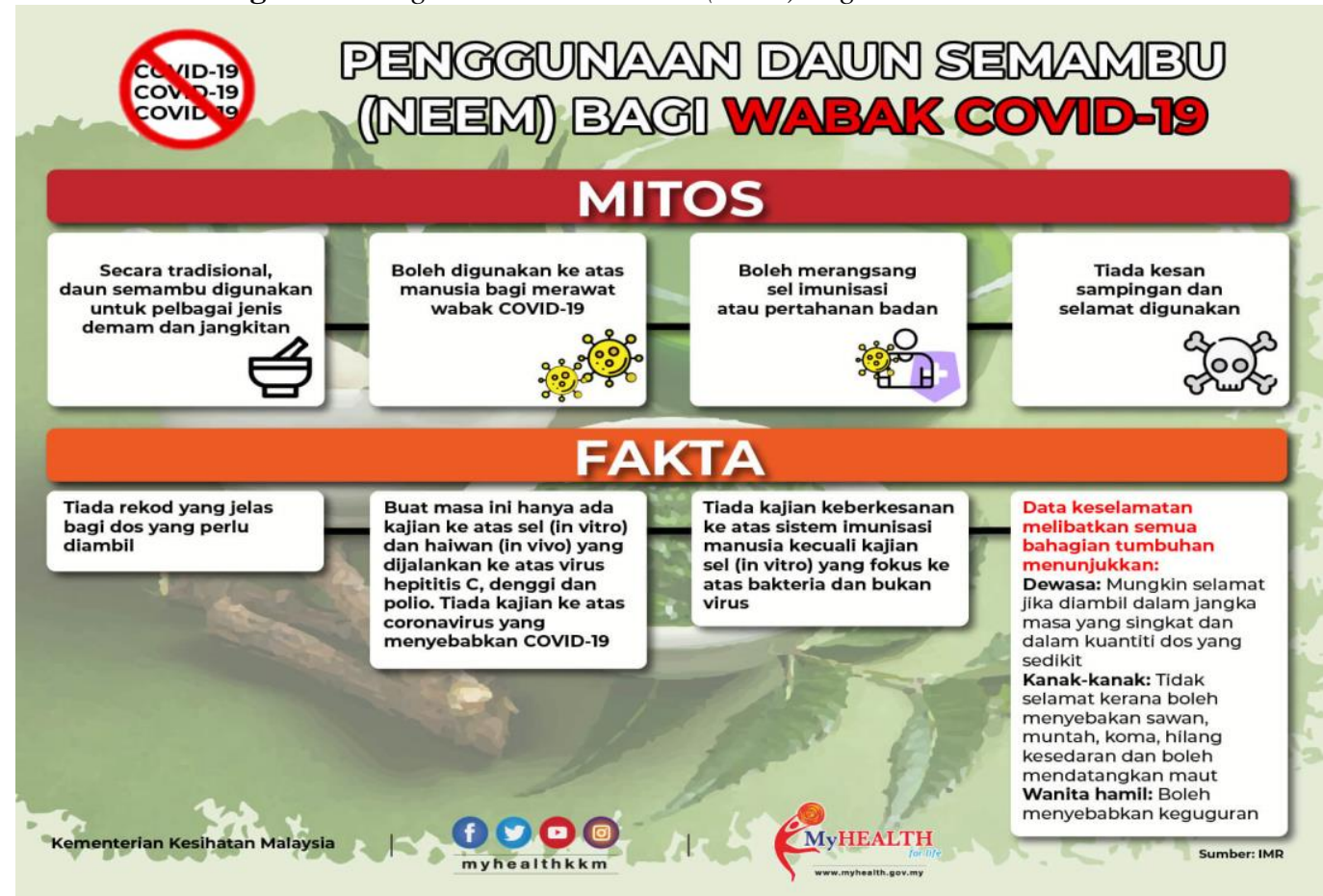

Source: Ministry of Health Malaysia (2020) at http://covid-19.moh.gov.my/infografik 
The same applies to the use of process-based infographics to convey information about COVID19 preventive measures. These infographics not only divide complex tasks into simple components or steps (Knorr, 2019) but do so by incorporating images related to those components or steps so that the tasks can be understood more easily (Crane, 2016). An example of this can be viewed in the Langkah cuci tangan menggunakan hand sanitizer (Hand washing steps using hand sanitizer) (Figure 3) infographic under the Pencegahan (Prevention) infographic group. The infographic details a step by step guide to effective hand washing as one of the simplest methods of reducing the spread of COVID-19. Another example can be observed in the Jom! Kita buat senaman gym di rumah! (Let's do gym exercise at home!) infographic under the PKP-MCO infographic group (Figure 4). This infographic gives step-by-step instruction for performing a gym workout routine at home without going to the gym, which is not permitted during the movement control order period.

Figure 3: Langkah cuci tangan menggunakan hand sanitizer

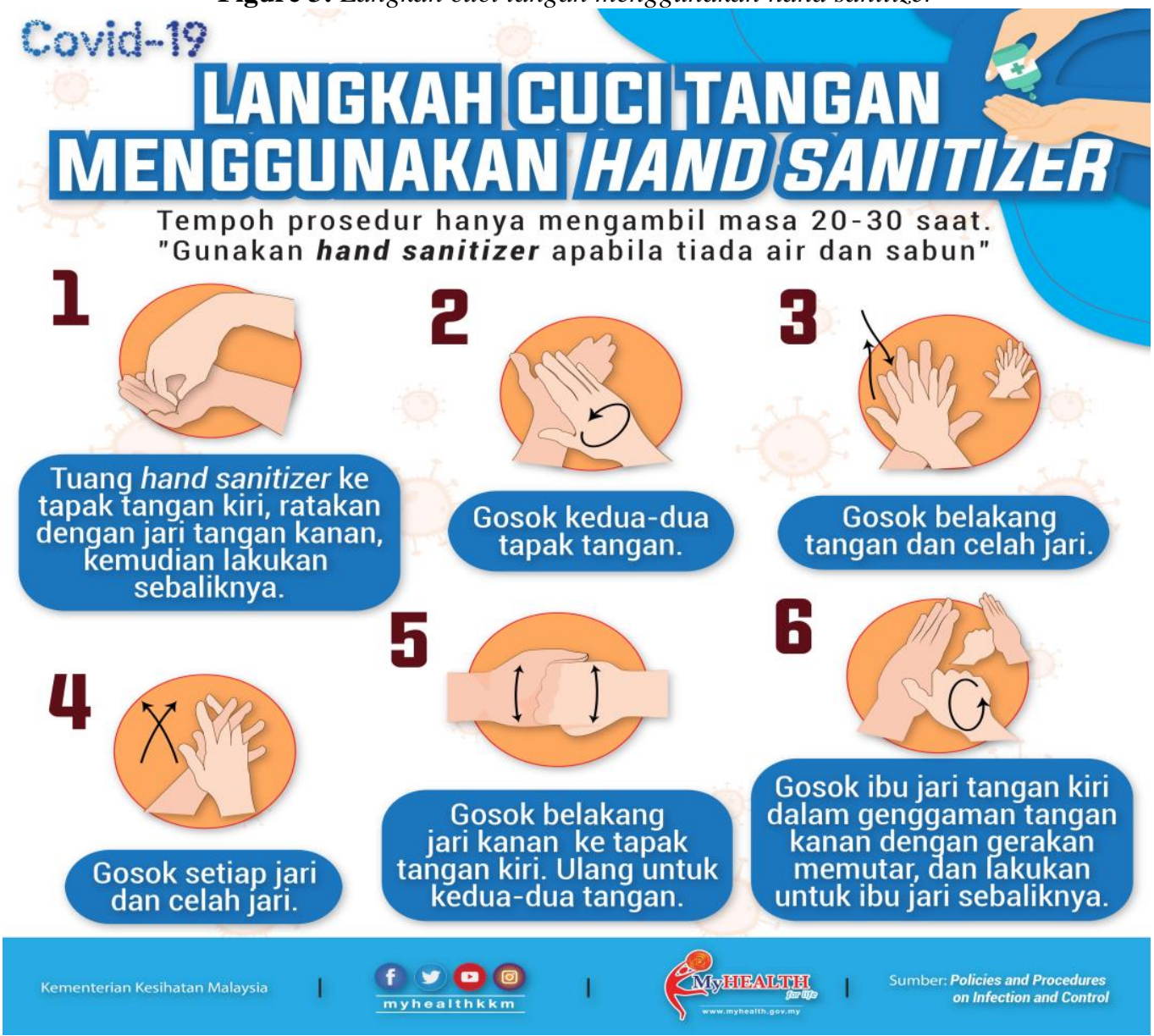

Source: Ministry of Health Malaysia (2020) at http://covid-19.moh.gov.my/infografik

Figure 4: Jom! Kita buat senaman gym di rumah! 


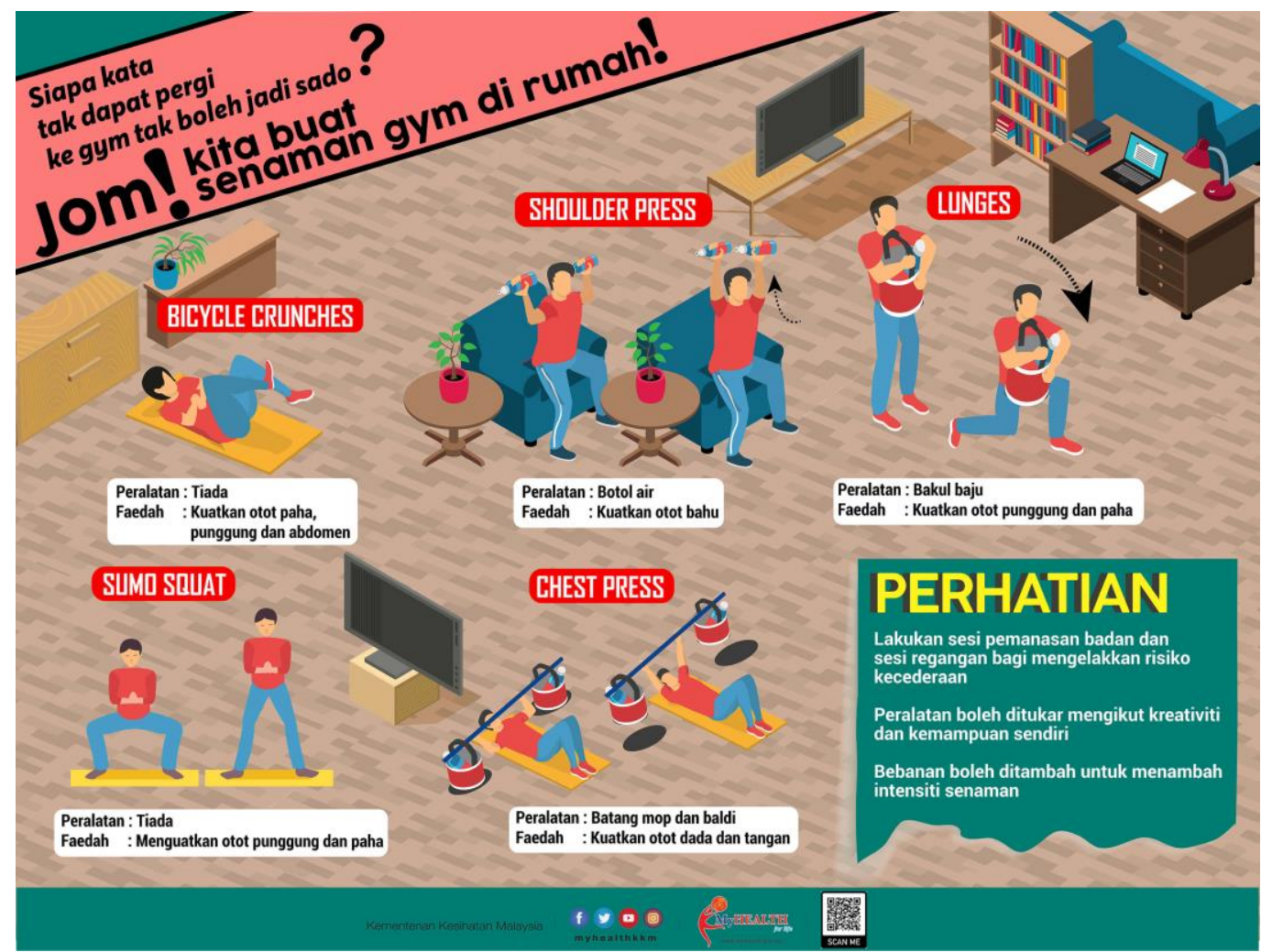

Source: Ministry of Health Malaysia (2020) at http://covid-19.moh.gov.my/infografik

In terms of the components of infographics, all COVID-19 PSA infographics produced by MOH possess the following components as summarized in Table 4.

Table 4: MOH Infographics and Their Components

Components

Story

Style

\section{Summary}

The 'story' or the main message of all $\mathrm{MOH}$ infographics is clearly and visibly indicated in their respective headings, which is further reinforced in their individual content or body of the information.

The style of all MOH infographics includes a color palette of at least two main colors, a single font type, a hierarchy of headings, and the size of images to help the target audience visualize the information more easily.

Almost all MOH infographics use facts to


support the main message, except for a few of those that use minimal statistics, observed in the Kesiapsiagaan Hospital Kementerian Kesihatan Malaysia Dalam Menangani COVID-19 (Preparedness of Ministry of Health Malaysia Hospitals In Managing COVID-19) infographic.

The component of simplicity is evident in all $\mathrm{MOH}$ infographics through the use of at least one main font style with two sizes to show importance (e.g., larger size for the heading, Simplicity smaller size for the content), a two-color palette, and simple graphics. The simplicity provides the target audience with a visual signal that helps the eye moves quickly over the main message.

Size

Almost all MOH infographics adhere to the rule related to 'size' of presenting the information concisely (i.e., not too short and not too long), except for a few that either offers a lengthy explanation as shown in the Perintah Kawalan Pergerakan (Movement Control Order) infographic or contain a fullblown image of Scan Me QR code in the Maklumat Penting COVID-19 (COVID-19 Important Information) infographic.

\begin{tabular}{cl}
\hline \multicolumn{1}{c}{ Sources } & $\begin{array}{l}\text { All MOH infographics are composed of } \\
\text { internal data (MOH as the information } \\
\text { source) except for a few that indicate or list } \\
\text { the sources (sumber). }\end{array}$ \\
\hline Shareability & $\begin{array}{l}\text { The component of shareability is evident in } \\
\text { almost all MOH infographics and this is } \\
\text { clearly and visibly indicated either through } \\
\text { the Scan Me QR Code that can be found at } \\
\text { the bottom part of the infographic or the use } \\
\text { of hashtags such as \#KitaTeguhKitaMenang } \\
\text { (We will win if we stick together) and } \\
\text { \#stayathome. }\end{array}$ \\
\hline \hline
\end{tabular}




\subsection{Three-way Process of Engaging the Public}

Regardless of types and topic, all MOH infographics adopt the three-way process in engaging the general public: raising awareness, changing and challenging attitudes, and presenting a call to action. This is achieved through a particular way that each infographic takes to present both textual and graphical information to engage the target audience.

The use of formatted icons and sections in the Pengunaan daun semabu (neem) bagi wabak COVID-19 (The use of neem for COVID-19 epidemic) infographic, for instance, not only help raise people's awareness about the myths and facts of using neem. Such presentation style also helps them to challenge those myths so that they can understand the real fact that there is no current cure or vaccine for COVID-19. Although there is no direct mention of a call to action to stop using neem, the mitos (myths) and fakta (facts) laid out by the infographic are sufficient to persuade or convince the public to act wisely.

The easy to follow instructions as observed in the Langkah cuci tangan menggunakan hand sanitizer (Hand-washing steps using hand sanitizer) and the Jom! Kita buat senaman gym di rumah! (Let's do gym exercise at home!) infographics not only raise people's awareness of good hand hygiene, on the one hand, and good workout routine, on the other hand. These infographics also help people change and/or challenge their current attitudes towards hand sanitizer and infection prevention (i.e., it is impossible to wash hands without soap and water) and working out at home during the movement control order period (i.e., working out at home is not possible). While there is no direct mention of a call to action in the hand sanitizer infographic, it relies on other media communication channels such as the newspapers, radio, and television broadcasts through which $\mathrm{MOH}$ reminds the general public of the importance of practicing good hand hygiene as a means to prevent the spread of the novel disease. This is in contrast to the home workout infographic that presents a call to action through the use of the Malay slang word, Jom (Let's go) in the main heading and the interrogative slogan, Siapa kata tak dapat pergi ke gym tak boleh jadi sado? (Who says you can't be strong and muscular if you can't go to the gym?). This heading and slogan may entice people (men in general) into adopting healthier behavior in minimizing the health risks during the movement control order.

Several points can be gleaned from the above findings. First, there is a considerable number of infographics that $\mathrm{MOH}$ produced during the COVID-19 pandemic period, targeting the general public and specific segments of the population (e.g., healthcare workers, public servants, taxi drivers). Second, the infographics provide essential information that the lay people need to understand about the disease, its risks, and ways to prevent its spread. Third, the infographics convey this essential information easily and vividly through the most common infographic types (e.g., informational and process-based) and the key components they possess. Finally, the infographics engage the target audience with the intended message by adopting the three-way process of promoting awareness, altering attitudes, and offering a call to action. However, there some issues that may arise from the above-mentioned infographics.

First, there may be issues whether the infographics communicate the intended messages to the 'right' audience at the 'right' time in the 'right' manner. While there is no doubt about the timing of these infographics as they are produced and disseminated during the pandemic period, one is tempted to ask whether they reach a much wider audience from different social and cultural 
backgrounds and whether they take into account the level of people's social media literacy and their experience using digital media technologies. These issues become more apparent if one considers the facts below:

1. The infographics are mostly written in Malay, except for only one Chinese language infographic. Although there are some English language infographics, one must consider Malaysia's vast and diverse population and that not everyone can speak or understand the language despite its widespread use. The use of popular Malay urban slang and catchphrase (e.g., jom, sado), as well as Malay forms of address (e.g., Makcik Kiah, Cik Kiah, Tok Ayah) in the message contents, could potentially exacerbate this language use issue mainly because not everyone is familiar with these words or terms.

2. The infographics frequently employ scientific or medical terms to describe the disease, its risks, and prevention measures (e.g., face mask, hand sanitizer, front-liner). This comes as no surprise as the terms are needed to explain the spread of COVID-19 and the ensuing pandemic. Such terms, however, may not be easily understood by those who are less educated, who are older, and/or who live in isolated or remote rural areas across the country.

3. A small portion of the infographics features the Scan Me QR code image as the message content, with no information about the novel virus. Of course, one needs to scan the image to access the information. However, we cannot assume that everyone who owns a smartphone or any devices connected to the Internet can do so. ${ }^{3}$

The facts above echo some of those raised by Kadri et al., (2016) regarding the need for effective infographic design and dissemination during disease outbreaks. As mentioned in an earlier section, Kadri et al., (2016) argued the main issue concerning India's Zika virus infographics revolved around English as the language in conveying messages about the virus to the masses. Given the vast and diverse population of India, Kadri et al., (2016) call for the need of producing Zika virus infographics that are tailored to the language, readability level, and culture of local people in India. The same can be said of Malaysia: COVID-19 PSA infographics should consider the nation's diversity and people's various levels of social media literacy.

Second, there may be issues concerning whether the infographics are designed in keeping with the principles of message design in health risk communication materials, which include the use of more visual displays (Lipkus \& Hollands, 1999) and individual experiences (Lipworth, Davey, Carter, Hooker, \& Hu, 2010) to gauge people's trust and confidence, as opposed to numerical (Kreuter et al., 2007) and negative information (Covello, Peter, Wojtecki, \& Hyde, 2001). There

\footnotetext{
${ }^{3}$ This observation is made because $\mathrm{MOH}$ relies heavily on the Internet and digital media technologies to disseminate its COVID-19 PSA infographics. The surveys conducted by the Malaysian Communications and Multimedia Commission (MCMC), namely the Handphone Survey 2018 and Internet Usage 2018, may explain why some segments of the Malaysian public are not able to access these infographics. Both surveys reveal that there are more handphone and internet users among urban dwellers compared to those living in the rural areas despite many initiatives taken by local authorities to close the gap (i.e., a ratio of 1.79 urban handphone users to 1.0 rural handphone users, and a ratio of 2.3 urban internet users to 1.0 rural internet users). More information about the surveys can be found at https://www.mcmc.gov. my/skmmgovmy/media/General/pdf/HPUS2018.pdf https://www.mcmc.gov.my/skmmgovmy/media/General/pdf/Internet-Users-Survey-2018.pdf
} 
is no doubt that the infographics explicitly rely on the visual display of information. One infographic, however, presents individual experiences with the disease. This can be seen in the Terima-kasih Malaysia (Thank you Malaysia) infographic that displays a thank-you note from a Chinese national who recovered from the disease under the care of the MOH hospital. Nevertheless, there are a few infographics that contain numerical data (e.g., Preparedness of $\mathrm{MOH}$ hospitals in managing COVID-19) and negative information (e.g., the death skull icon in the use of neem infographic). This comes as no surprise in a context where there is a lack of awareness of the fatality of COVID-19 cases in Malaysia, which explains why such information is needed rather than avoided to drive the general public into action.

Third, there may be issues whether infographics have a 'real' impact on people's behaviors and daily lives during the pandemic period. Of course, there is no denying that the infographics engage the target audience through information visualization and graphical representation of data. More needs to be known about the extent to which these infographics raise people's awareness about the disease, change and challenge their attitudes and take up the call to action in adopting recommended preventive and control measures.

\section{CONCLUSION}

The main aim of this article has been to examine Malaysia's COVID-19 PSA campaign, with a specific focus on the COVID-19 PSA infographics produced thus far. The analysis of the preliminary data shows that there is a considerable number of infographics designed and disseminated by the country's Ministry of Health. This is evidenced by the common infographic types used and the various topics covered, as well as the key components and the three-way process of information conveyance that these infographics utilized. All these help MOH convey accurate and much-needed information to the general public in times of health outbreak.

Whether the lay public will heed MOH COVID-19 message and call to action is intriguing and worthy of further investigation. On a related note, the analysis raises pertinent issues concerning whether the infographics are designed in keeping with the principles of message design in health risk communication. Finally, what has been shown here reflects a glimpse of Malaysia's current, ongoing initiatives in managing the COVID-19 pandemic, especially where healthcare and health risk communication are concerned. The article acknowledges that the results are not representative of COVID-19 PSA infographics produced locally by other government agencies and non-governmental organizations. At most, the results provide a basis for further studies of these infographics in terms of their production and dissemination during acute health conditions.

\section{ACKNOWLEDGEMENT}

The authors would like to thank the Ministry of Health Malaysia for making the COVID-19 infographics accessible on its official website. Any inaccuracies are the authors' own responsibility. 


\section{REFERENCES}

Abd Latiff, D. I., Mohd Zulkifli, M. A. A., \& Abd Ghani, S. N. F. (2013). The influences of Malaysian animated public service announcements (PSAs) on public health and safety campaigns and their effectiveness among students. Social and Management Research Journal, 10(2), 73-89.

Balkac, M., \& Ergun, E. (2018). Role of infographics in healthcare. Chinese Medical Journal, $131,2514-2517$

Chan, K., \& Chang, H. C. (2013). Advertising to Chinese youth: A study of public service ads in Hong Kong. Qualitative Market Research, 16(4), 421-435.

Chan, W. K. (2020, March 15). 'Covid-19 hour' tomorrow? Fake news, says health ministry. The Malay Mail. Retrieved from https://www.malaymail.com/news/malaysia/2020/03/15/ covid-19-hour-tomorrow-fake-news-says-health-ministry/1846866

Covello, V. T., Peters, R. G., Wojtecki, J. G., \& Hyde, R. C. (2001). Risk communication, the West Nile virus epidemic, and bioterrorism: responding to the communication challenges posed by the intentional or unintentional release of a pathogen in an urban setting. Journal of Urban Health, 78(2), 382-391.

Crane, B. E. (2016). Infographics: A Practical Guide for Librarians. Lanham: Rowman \& Littlefield.

Dur, B. I. U. (2014). Interactive infographics on the internet. Online Journal of Art and Design, 2(4), 1-14.

Dzulkifli, A. R. (2020, March 20). Winning the Covid-19 war. New Straits Time. Retrieved from https://www.nst.com.my/opinion/columnists/2020/03/576467/winning-covid-19-war

Gamage, S. D., Kralovic, S. M., \& Roselle, G. A. (2010). Emerging infectious diseases: Concepts in preparing for and responding to the next microbial threat. In K. Koenig \& C.H. Schultz (Eds.), Koenig and Schultz's disaster medicine: Comprehensive principles and practices (pp.75-102). New York: Cambridge University Press.

Huang, P. (2020). The Coronavirus crisis: Explainer - What does the World Health Organization do? Retrieved from https://www.npr.org/sections/goatsandsoda/2020/04/28/847453237/ what-is-who-and-what-does-it-do

Kadri S. M., Rehman, S. -ur., Rehana, K., \& Gergianaki, I. (2016). Zika virus disease (ZIKV) infographics, language-tailored: Innovations and good practices in integrated disease surveillance program Kashmir, India 2016. Journal of MPE Molecular Pathological Epidemiology, 2(S1), 1-4.

Knorr, A. (2019). Infographics: A powerful combination of words, images, and data. In L. A. Sabatino \& B. Fallon (Eds.), Multimodal composing: Strategies for twenty-first-century writing consultations (pp. 97-109). Louisville: Utah State University Press.

Kreuter, M. W., Green, M. C., Cappella, J. N., Slater, M. D., Wise, M. E., Storey, D., Clark, E. M., O’Keefe, D. J., Erwin, D. O., Holmes, K., Hinyard, L. J., Houston, T., \& Woolley, S. (2007). Narrative communication in cancer prevention and control: A framework to guide research and application. Ann Behav Med, 33(3), 231-235.

Krum, R. (2014). Cool Infographics: Effective Communication with Data Visualization and Design. Indianapolis: John Wiley \& Sons, Inc.

Laan, S. (2013). Infographic: Healthcare industry building trust through social media. Infographic Achieve. Retrieved from https://www.infographicsarchive.com/infographichealthcare-industry-building-trust-through-social-media/ 
Lankow, J., Ritchie, J., \& Crooks, R. (2012). Infographics: The Power of Visual Storytelling. Hoboken: John Wiley \& Sons.

Lipkus, I. M., \& Hollands, J. G. (1999). The visual communication of risk. JNCI monographs, 1999(25), 149-163.

Lipworth, W. L., Davey, H. M., Carter, S. M., Hooker, C., \& Hu, W. (2010). Beliefs and beyond: what can we learn from qualitative studies of lay people's understandings of cancer risk? Health Expectations, 13(2), 113-124.

Martiniuk, A., Secco, M., Yake, L., \& Speechley, K. N. (2010). Evaluating the effect of a television public service announcement about epilepsy. Health Education Research, 25(6), 1050-1060.

McCrorie, A., Donnelly, C., \& McGlade, K. J. (2016). Infographics: Healthcare communication for the digital age. Ulster Med J, 85(2), 71-75.

Ministry of Health Malaysia (MOH) (2020). COVID-19 infografik. Retrieved from http://covid19.moh.gov.my/infografik

Omar, A. H. (2016). Positioning languages in the Malaysian education system. In A. H. Omar (Ed.), Languages in the Malaysian education system: Monolingual strands in multilingual settings ( $1^{\text {st }}$ ed., pp. 1-30). Oxon: Routledge.

Palansamy, Y. (2020, March 31). Ministry's MCO advice to women: Wear make-up while working at home, speak to spouse in Doraemon voice and giggle coyly. The Malay Mail. Retrieved from https://www.malaymail.com/news/malaysia/2020/03/31/ministrys-mcoadvice-to-women-wear-make-up-while-working-at-home-speak-to-s/1851985

Rekhraj, H. S. (2015, April 25). The power of PSAs. The Star. Retrieved from https://www.thestar.com.my/news/education/2015/04/26/the-power-of-psas

Schroeder, J., Plapper, E., Zeng, H., \& Krile, B. (2016). Public perception of safety messages and public service announcements on dynamic message signs in rural areas. Retrieved from https://ops.fhwa.dot.gov/publications/fhwahop16048/fhwahop16048.pdf

Scott, H., Fawkner, S., Oliver, C., \& Murray, A. (2016). Why healthcare professionals should know a little about infographics. British Journal of Sports Medicine, 50(18),110141105.

Shin, H. (2016). Epidemic and Risk Communication: An Analysis of Strategic and Graphic Characteristics of Infographics (Unpublished Master's Thesis). USA: Iowa State University.

Siricharoen, W. V., \& Siricharoen, N. (2015). How infographics should be evaluated. Retrieved from http://icit.zuj.edu.jo/icit15/DOI/Multimedia_and_Its_Applications/0100.pdf

Smith, D. S., \& Birtwhistle, R. (2012). Exploring patient perceptions of PSA screening for prostate cancer: Risk, effectiveness, and importance. Canadian Family Physician, 58(9), e502-e507.

Soo, W. J. (2020, April 19). Want to win Covid-19 fake news war? Make information readily available, human rights groups tell govt. The Malay Mail. Retrieved from https://www.malaymail.com/news/malaysia/2020/04/19/want-to-win-covid-19-fakenews-war-make-information-readily-available-human/1858143

Stones, C., \& Gent, M. (2015a, July 14-15). "If The Guardian can do it, we should be able to do it!" Examining public health infographic strategies used by public health professionals. In: Design4Health 2015 proceedings. Design4Health 2015. Sheffield Hallam University. Stones, C., \& Gent, M. (2015b). The 7 G.R.A.P.H.I.C. Principles of Public Health Infographic Design. Leeds: University of Leeds. 
Sugget, P. (2019, June 25). Understanding public service announcements. The Balance Careers. Retrieved from https://www.thebalancecareers.com/what-exactly-is-public-serviceadvertising-38455

Rodriguez, R. A., \& Kissell, S. M. (2013). The medium and the message: Strategies for effective communication. In J. E. Fielding, S. M. Teutsch, \& S. N. Caldwell (Eds.), Public health practice: What works (pp. 66-75). New York: Oxford University Press.

Tan, J. (2020, April 1). Malaysian ministry's series of 'sexist' social posts a wake up call on purposeful PSA. Marketing Interactive. Retrieved from https://www.marketinginteractive.com/malaysian-ministry-s-series-of-sexist-social-posts-a-wake-up-call-onpurposeful-psa

Tran, T., Valecha, R., Rad, P., \& Rao, H. R. (2020, December 21-22). An investigation of misinformation harms related to social media during humanitarian crises. In S. K. Sahay, N. Goel, V. Patil, \& M. Jadliwala (Eds.), Secure knowledge in artificial intelligence era: Proceeding of $8^{\text {th }}$ international conference, SKM 2019 (pp. 167-181). Goa, India.

World Health Organization (WHO) (2020). COVID-19 infographics. Retrieved from https://www.who.int/westernpacific/news/multimedia/infographics/covid-19 